\title{
Evaluation of land suitability for Oilseeds crops (Sesame and Groundnut) using GIS and Multi- criteria evaluation: A case study of Diga District, East Wollega Zone, Western Ethiopia
}

Biratu Bobo Merga ( $\square$ bira2bobo@gmail.com )

Oda Bultum University https://orcid.org/0000-0002-7249-7576

Mitiku Badasa Moisa

Wollega University

Dessalegn Obsi Gemeda

Jimma University College of Agriculture and Veterinary Medicine

\section{Research Article}

Keywords: Land suitability, Sesame, Groundnut, MCE, Diga district

Posted Date: October 29th, 2021

DOI: https://doi.org/10.21203/rs.3.rs-1014922/v1

License: (c) (1) This work is licensed under a Creative Commons Attribution 4.0 International License.

Read Full License 


\section{Abstract}

Sesame and groundnut crops are the major oilseeds crops produced for exports and local consumptions in the Ethiopia. This study attempted to evaluate land suitability for oilseeds crops using Geographic Information Systems (GIS) and Multi-criteria evaluation (MCE), in the case of Diga district, East Wollega zone, Western Ethiopia. By integrating GIS and MCE techniques land suitability maps for sesame and groundnut were produced. Climate data (Temperature and rainfall), topography data (Slope), soil data (Soil texture, soil depth and soil drainage), infrastructure data (Road and market) were used in this study. The result of the study revealed that, about 252.1 ha $(0.4 \%)$ and $113.1 \mathrm{ha}(0.2 \%)$ were highly suitable for sesame and groundnut crops, respectively. Our results show that most parts of the study area were moderately suitable for sesame and groundnut production. Specially, the central and western parts of the study area are highly suitable and moderately suitable for sesame production. Findings of this study can support the farming communities and decision makers through providing highly productive areas for sesame and groundnut production.

\section{Introduction}

Both groundnut and sesame are an oil crops grown in hot dry areas. They share similar physical environment. Ethiopia is an agrarian country and the majority of the populations depend on cereal crops. The population is increasing at an alarming rate with limited resources, which requires urgent attention from scholars and decision makes to feed the growing population. Because of agro ecological variation, the country has a great potential to cultivate different varieties of crops. However, lack knowledge about the potential suitability of land for different crops is a main barrier to agricultural diversification (Jahanshiri et al., 2020).

Lack of knowledge on crop and land suitability is resulted in neglecting of high value oil crops like sesame and groundnut. Oilseed plays a key role in national economy and generating foreign exchange earnings (Sori, 2021; Chala et al., 2014; Zarihun 2012). From oilseed crops, sesame and groundnuts are the major crops cultivated in Ethiopia and contributed to national economy. It is the 2 nd agricultural export earnings of Ethiopia following coffee. Sesame and groundnut crops are suitable for tropical and sub-tropical region (Al-Mashreki et al., 2015; Girmay, 2015) with some preference of soil, temperature and precipitation.

Sesame is considered as a queen of oil seeds (Weiss, 2000). It contains oil, protein, carbohydrates, and Vitamin B and E (Myint et al., 2020). Moreover, sesame has the potential to resist drought occurrence (Bekele et al., 2017), and can support the life of rain-fed dependent communities under with little precipitation. This crop is highly flexible and can adapt long growing seasons and well drained soils (Girmay, 2015; Zarihun, 2012). Sesame is one of the major economically important crops in Ethiopia (Baraki and Berhe, 2019). 
Groundnut is used for oilseed, food and animal feed across the world (Upadhyaya et al., 2006; Pande et al., 2003). This oilseed is mainly produced by smallholders in Ethiopia particularly in the lowland areas (Chala et al., 2014). Groundnut farming was introduced to Ethiopia by Italian explorers in 1920 (Tekulu et al., 2020). Currently, groundnut support substantial number of smallholder's farmers in western Oromia (Sori, 2021). Groundnut can provide good yield and yield quality under good management systems. In spite of the economic importance, less emphasis was given to expand groundnut farming.

To get better yield and high-quality oilseed crops (Sesame and groundnut), potential land suitability assessment is a pre-request task for scholars and decision makers. Geographic Information Systems (GIS) and Multi-Criterion Evaluation (MCE) is an important tool to identify potential suitable areas for crops in order to increase production, and manage the land in their care more efficiently (Aspinall et al., 1995). The use of technology like GIS to identify the best suitable land in general and crop suitability classification in particular has been increasing over the past decades (FAO, 1997). In order to consider sustainable agricultural land use in Ethiopia, crop suitability analysis that incorporates the land use characteristics is very essential. Thus, this study attempted to evaluate the potential suitable land for sesame and groundnut production in Diga district, East Wollega zone, Western Ethiopia.

\section{Materials And Methods}

\subsection{Description of the study area}

Administratively, Diga district is located in East Wollega zone Oromia National Regional state, western Ethiopia. Astronomically, the study area lies between $8^{\circ} 56^{\prime} 00^{\prime \prime}$ and $9^{0} 10^{\prime} 00^{\prime \prime} \mathrm{N}$ and $36^{\circ} 9^{\prime} 00^{\prime \prime}$ and $37^{0} 31^{\prime} 00^{\prime \prime}$ E (Figure 1). The altitude of the study area lies between $2340.95 \mathrm{~m}$ and $1114.25 \mathrm{~m}$ above mean sea level. It covers an area of about $58,633 \mathrm{ha}$. The distribution of rainfall and temperature of the district are strongly related to the elevation. The average annual temperatures of Diga district was from $18.7^{\circ} \mathrm{C}$ to $22.6^{\circ} \mathrm{C}$. Yearly maximum temperature is showed at the low land areas and lower temperature is categorized in high land areas of Diga district (Sori and Ketema, 2017).

\subsection{Data Types and Sources}

In this study, different types of data were used for physical land suitability for both sesame and groundnut cultivation. These data are climate data (Rainfall and Temperature) and soil properties such as: soil texture, soil drainage, and soil depth and DEM (Digital Elevation Model) data for slope generation. Details of data sources are listed in (Table 1). 
Table 1

Data Types and sources

\begin{tabular}{|lll|}
\hline S/No & Data Types & Sources \\
\hline 1 & Temperature and Rainfall data & National Metrological Agencies (NMA) \\
\hline 2 & $\begin{array}{l}\text { Soil data (Depth, Texture and Drainage by } \\
1: 1000,000)\end{array}$ & $\begin{array}{l}\text { Ministry of Agriculture and ISRIC Africa soil } \\
\text { database }\end{array}$ \\
\hline 3 & Digital Elevation Model & ASTER website \\
4 & Road and Market(Town) & Ethiopian mapping agency \\
\hline
\end{tabular}

Different software were used for analyzing land suitability for sesame and groundnut crops. Types and purposes of software are listed in (Table 2).

Table 2

Software Packages

\begin{tabular}{|lll|}
\hline S/No & Software used & Application \\
\hline 1 & ArcGIS 10.3 & Data visualization and map layout \\
\hline 2 & ERDAS IMAGINE 2015 & Image preprocessing and Classification \\
\hline 3 & IDRISI Selva 17 & Weighting Influencing percentage \\
\hline
\end{tabular}

\subsection{Data Analysis}

To evaluate the physical land suitability for sesame and groundnut Geographic Information System (GIS) and multi criteria evaluation techniques were employed to select suitable sites for both sesame and groundnut cultivation. For this purpose, various thematic (information) layers such as slope, soil texture, soil depth, soil drainage, rainfall, temperature, road and towns (Figure 2) maps were generated in ArcGIS 10.3. Each vector layers were rasterized by taking weight as a feature class. All the factors and constrains were classified in to four classes namely; highly suitable, moderately suitable, marginally suitable and not suitable with values ranging from 1 to 4 , where value of 4 represents the most suitable and value 1 indicates the least suitable for all factors and constraints were considered. Weights for each class of criteria were derived in IDRISI software using AHP methods. The method uses the expert preferences for comparing the classes and prepare matrix table. Using these thematic layers as factors, criteria maps were generated by applying spatial Analytic Hierarchy Process (AHP). Accordingly, weights were derived for each class giving total sum of 1 .

In this study different scenarios were produced by giving different preference values to decision factors. Since the prime matter in Multi-Criteria Evaluation (MCE) is concerned with how to combine the 
information from several criteria to form a single index of evaluation, series of base maps and images were prepared to facilitate the processing, data integration and functionality of GIS software (Kassaye et al., 2019). The data were collected in both raster and vector format. The factors were weighted by a pairwise comparison matrix (Saaty, 1977 and 1980) and the relative importance of the factors was computed by normalizing the eigenvector of the factors by their cumulative totality. The total weights of the factors were dispersed to the different levels of suitability classes by an equal interval ranging techniques. In the class breakdown was determined by the weight of the factor divided by the number of classes. The method was illustrated through a case study for site suitability of Diga district for its Sesame and Groundnut cultivation using GIS and remote sensing based multi-criteria evaluation technique.

\subsection{Factors used to map physical land suitability for Sesame and Groundnut crops}

We evaluated the suitability of land for sesame and groundnut through considering environmental variables such as soil, topography and climate. Figure 3 clearly reveals that potential soil suitability for both sesame and groundnut.

\subsubsection{Soil Texture}

Soil properties are the main important factor to get potential land for sesame and Groundnut production. There are three types of soil textures in the study area; namely, loam sand, sandy loam and sand clay loam.

\subsubsection{Soil drainage}

Soil drainage was another factor of soil properties that used in this study. Four types of drainage exist in the study area, such as; well, moderate, somewhat excessive and imperfect. According to Al-Mashreki et al., (2015) stated that Well and moderate drainage were more suitable for sesame and groundnut crops cultivation. The left one was marginally and not suitable respectively.

\subsubsection{Soil depth}

Soil depth is the most important soil properties that used for finding potential land for sesame and groundnut production (Kindu et al., 2009). Deep soil depth is highly suitable for sesame and groundnut land suitability. Slightly shallow and very shallow were not suitable for site suitability of these crops.

\subsubsection{Infrastructures (Road and Market)}

Figure 4 shows that temperature, rainfall, slope and road map the study area.

\section{Road and market}

Road facility is another factor for physical land suitability of sesame and groundnut crops production. To transport the crop yield from the cultivated land and to market to sale the product the suitability land 
should be close to road. So, the land more close to the road is highly suitable for sesame and groundnut crops production (Debasa et al., 2020). Based on the previous studies road was reclassified in to four (more closed to far apart). To minimize the cost of transportation the suitability area close to market is highly suitable.

\subsubsection{Slope}

Slope is a measure of terrain steepness i.e., the degree to which land is not horizontal. It affects agricultural productivities in different parts. It is one of the most important factors that affect the physical land suitability of sesame and groundnut crops production. In this study, slope was reclassified in to four different categories based on percent rise as (0-5, 5-10, 10-20 and >20). According to Al-Mashreki et al., (2015) flat or gentle slope is highly suitable for sesame and groundnut production; whereas, steep slopes are more difficult to cultivate and more likely to lose soil and nutrients through erosion. Due to these factors, steep slope is not suitable for cultivation of sesame and groundnut crops.

\subsubsection{Climate (Temperature and rainfall)}

Temperature and rainfall were reclassified based on references from cold temperature to warm temperature as well as low rainfall to high rainfall (Figure 4A and Figure 4B). Warm temperature and medium rainfall were highly suitable for sesame and groundnut crops cultivation. Kindu et al. (2009) also pointed out that both groundnut and sesame share similar physical environments, mainly temperature and rainfall.

\subsection{Procedure of physical land suitability evaluation}

Based on the FAO (1976) and on the basis of growth and production requirements of each crops we assessed the physical land suitability of sesame and groundnut cultivation in the Diga district, East Wollega zone. Major environmental variables such as climate data (Temperature and Rainfall), topography (slope), infrastructures (Road and Market) and soil, data (Soil drainage, Soil Texture and soil depth) were analyzed for physical land suitability for sesame and groundnut crops cultivation in the study area. These factors are listed in (Table 3) with their suitability. 
Table 3

Factors and suitability classes for sesame and groundnut crops cultivation

\section{S/No Land characteristics Class and degree of limitation}

\begin{tabular}{|c|c|c|c|c|c|}
\hline & Suitability classes & S1 & $\mathrm{S} 2$ & S3 & N1 \\
\hline \multirow[t]{3}{*}{1} & Climate & & & & \\
\hline & Temperature (0C) & $>22$ & $21-22$ & $19-21$ & $<19$ \\
\hline & Rainfall (mm) & $<1458$ & $1458-1494$ & $1494-1534$ & $>1534$ \\
\hline \multirow[t]{2}{*}{2} & Topography & & & & \\
\hline & Slope (\%) & $0-5$ & $5-10$ & $10-20$ & $>20$ \\
\hline \multirow[t]{4}{*}{3} & Soil properties & & & & \\
\hline & Soil depth(cm) & $>100$ & $75-100$ & $50-75$ & $<50$ \\
\hline & Soil Texture & $\begin{array}{l}\text { Loam } \\
\text { sand }\end{array}$ & $\begin{array}{l}\text { Sandy clay } \\
\text { loam }\end{array}$ & Sandy loam & - \\
\hline & Drainage & Well & Moderate & $\begin{array}{l}\text { Somewhat } \\
\text { excessive }\end{array}$ & Imperfect \\
\hline \multirow[t]{3}{*}{4} & Infrastructures & & & & \\
\hline & $\begin{array}{l}\text { Distance from } \\
\text { Market }\end{array}$ & $<5 \mathrm{~km}$ & $5-8 \mathrm{~km}$ & $8-10 \mathrm{~km}$ & $>10 \mathrm{~km}$ \\
\hline & Distance from Road & $<1 \mathrm{~km}$ & $1-2.5 \mathrm{~km}$ & $2.5-5.5 \mathrm{~km}$ & $>5 \mathrm{~km}$ \\
\hline
\end{tabular}

\subsubsection{Criteria Weight estimation by pairwise comparison}

Weight value from evaluation for the criteria was analyzed by using analytical hierarchy process (AHP) model based opinion of experts. According to Saaty (1980) confirmed that this techniques was established to compare each factor with other criteria, relative to its importance on the scale from 1 to 9 within the context of a multi-criteria decision process (Saaty, 2002). Lastly, from pairwise comparison matrix significances weight was computed in (Table 4). 
Table 4

Pair wise comparison matrix of parameter selected for this study

\begin{tabular}{|lllllllll|}
\hline Factors & Temp & Rainfall & Slope & Depth & drainage & Texture & Market & Road \\
\hline Temp & 1 & 2 & 2 & 2 & 2 & 3 & 3 & 4 \\
\hline Rainfall & $1 / 2$ & 1 & 2 & 2 & 2 & 3 & 3 & 4 \\
\hline Slope & $1 / 2$ & $1 / 2$ & 1 & 2 & 2 & 2 & 3 & 3 \\
\hline Depth & $1 / 2$ & $1 / 2$ & $1 / 2$ & 1 & 2 & 2 & 3 & 3 \\
\hline Drainage & $1 / 2$ & $1 / 2$ & $1 / 2$ & $1 / 2$ & 1 & 2 & 2 & 3 \\
\hline Texture & $1 / 3$ & $1 / 3$ & $1 / 2$ & $1 / 2$ & $1 / 2$ & 1 & 2 & 3 \\
\hline Market & $1 / 3$ & $1 / 3$ & $1 / 3$ & $1 / 3$ & $1 / 2$ & $1 / 2$ & 2 & 2 \\
\hline Road & $1 / 4$ & $1 / 4$ & $1 / 3$ & $1 / 3$ & $1 / 3$ & $1 / 3$ & $1 / 2$ & 1 \\
\hline$\Sigma=$ & 4.42 & 7.07 & 8.95 & 10.5 & 11.98 & 15.56 & 19.36 & 22.16 \\
\hline
\end{tabular}

Calculate to check the consistency of comparisons the consistency ratio (CR) to be requested (Saaty, 2002). The sum of weighted criteria must be equal to 1 . It ranges from 0 to 1 . A CR of 0.1 or $<0.1$ is a reasonable level of consistency (Saaty, 1980). Comparisons between 8 factors for physical land suitability were 0.04 , which shows logical decision.

Consistency index $(\mathrm{Cl})$ calculated from the following formula (Eq 1):

$$
C I=\frac{\lambda \max -n}{n-1}
$$

Where

$\lambda \max$ is the largest Eigen value of the pairwise comparison matrix and $\mathrm{n}$ is the number of classes.

Then, CR taken by the following formula (Eq 2) (Saaty, 1980)

$$
C R=\frac{C I}{R I}
$$

Where

$\mathrm{RI}$ is the ratio index/average value of $\mathrm{Cl}$ for random matrices using Saaty scale.

\subsubsection{Land suitability analysis}


A comprehensive evaluation of the physical setting for the study area revealed major environmental variables like climate, soil and topography for land suitability assessment. Weighted overlay for land suitability analysis was employed from all accumulated reclassified factors. Final land suitability map results for sesame and groundnut crops production was weight to each factor followed by collective of the factors (Habibie et al., 2019). According to Debesa et al (2020) and Rabia (2012) were confirmed that, the weights were developed by providing a series of pairwise comparison matrix of the relative importance of the factors to the suitability of the pixels for the activity was analyzed. To produce a set of weights that sum to one (Eq 9) the pairwise matrix comparisons were analyzed (Saaty, 2002).

\section{$S=\Sigma \mathrm{WiXi}$}

(Eq 9)

Where

$S$ is suitability, Wi is weight of factor, and $X i$ is criterion score of factor $i$.

\section{Results And Discussion}

\subsection{Land suitability for Sesame crop}

The land suitability results for sesame revealed that the highly suitable class (S1) accounts for 252.1 ha (0.4\%); whereas, moderately suitable class (S2) accounts for 16574.1 ha (28.3\%) which found in the western part of the study area. Final land suitability map of sesame crop cultivation was produced. Marginally suitable and not suitable are shared about $52.1 \%$ and $19.2 \%$ respectively. The result of this study was in consistent with Girmay, 2015 and Al-Mashreki et al., 2015 that topographic characteristics, the climatic conditions and the soil quality of the study area are the major determinant parameters of the land suitability evaluations. The detail information of this result was presented in (Table 5).

Table 5

Suitability area of sesame crop of the study area

\begin{tabular}{|llll|}
\hline S/No & Suitability classes & Area (ha) & Area (\%) \\
\hline 1 & Not suitable & 11234.7 & 19.2 \\
\hline 2 & Marginally suitable & 30572.2 & 52.1 \\
\hline 3 & Moderately suitable & 16574.1 & 28.3 \\
\hline 4 & Highly suitable & 252.1 & 0.4 \\
\hline & Total & 58633.0 & 100.0 \\
\hline
\end{tabular}

\subsection{Land suitability for Groundnut crop}

The result of this crop was aggregated from eight factors similar to sesame crops. The final map of land suitability for Groundnut crop was produced by multi-criteria evaluation based on the references of the 
previous studies. Land suitability results for groundnut indicated that the highly suitable class (S1) accounts for 113.1 ha $(0.2 \%)$; whereas 23123.1 ha (39.4\%) moderately suitable. The western part of the area was dominated by highly suitable and moderately suitable. Consequently, about $57.9 \%$ and $2.5 \%$ were dominated by marginally suitable and not suitable in the study area respectively (Table 6).

Table 6

suitability area of the groundnut in Diga district

\begin{tabular}{|llll|}
\hline S/No & Suitability classes & Area (ha) & Area (\%) \\
\hline 1 & Not suitable & 1475.4 & 2.5 \\
\hline 2 & Marginally suitable & 33921.4 & 57.9 \\
\hline 3 & Moderately suitable & 23123.1 & 39.4 \\
\hline 4 & Highly suitable & 113.1 & 0.2 \\
\hline & Total & 58633.0 & 100.0 \\
\hline
\end{tabular}

Based on this finding, it was found that there is a good potential land for both groundnut and sesame in the study area (Figure 5).

If land condition is improved and updated for current physical suitability with appropriate management practices, increased potential land suitability could be achieved. The result is in agreement with AlMashreki et al., (2015) that improved soil condition and inputs together with sustainable soil conservation are an important land management approaches to enhance sustainable productions in the study area.

\section{Conclusion}

Appropriate use of land depends on the fitness of the land for specific purposes. Effort has made to determine the suitable areas for oilseeds crops (Sesame and Groundnut) using Geographic Information System and Multi-Criteria Evaluation which becoming very useful techniques that to offer various opportunities to manage the land in their care more efficiently.

Several factors were used to evaluate land suitability of sesame and groundnut crop in the study area. These factors are; temperature, rainfall, slope, soil depth, soil texture, soil drainage, market and road were reclassified and overlaid by multi-criteria evaluation techniques. The result of this study shows that Diga district has more suitable land for cultivation of both sesame and groundnut. Most part of the study area is dominated by moderately suitable for sesame and groundnut crops production. Consequently, about 252.1 ha and 113.1 ha was highly suitable for sesame and groundnut crops respectively in Diga district. The study recommended that the local community should apply proper land management practices to increase these oilseeds for both subsistence and commercial. 


\section{Declarations}

Consent for publication: The authors agreed to publish the manuscript on journal of environmental and earth sciences.

Availability of data: Available in the manuscript

Code of Availability: Not applicable

Competing interest: the Authors declared no competing interests

Funding: No funding received for this research

\section{Contributions of Authors}

BBM participated in research design, data collection, and data analysis and draft manuscript. MBM participated in methodology. DOG works on literature and edits the manuscript to the journal style. All authors read and approved the final manuscript.

\section{References}

Al-Mashreki, M.H., Atroosh, K.B., Muflahi, A.A., Obaid, N.A., and Caoline, K. (2015). GIS-Based Assessment of Land Suitability for Industrial Crops (Cotton, Sesame and Groundnut) in the Abyan Delta, Yemen. American Journal of Experimental Agriculture 8(6): 384-405, 2015, Article no.AJEA.2015.183 ISSN: 2231-0606

Aspinall, R.J. (1995). Geographic information systems: their use for environmental management and nature conservation. Parks, 5: 20-31

Baraki, F., and Berhe, M. (2019). Evaluating Performance of Sesame (Sesamum indicum L.) Genotypes in Different Growing Seasons in Northern Ethiopia. International Journal of Agronomy Volume, Article ID 7804621, 7 pages https://doi.org/10.1155/2019/7804621

Bekele, A., Besufekad, Y., Adugna, S., Yinur, D., (2017). Screening of selected accessions of Ethiopian sesame (Sesame indicum L.) for salt tolerance. Biocatalysis and Agricultural Biotechnology. 9:82-94.

Chala, A., Abate, B., Taye, M., Mohammed, A., Alemu, T., and Skinnes, H. (2014). Opportunities and constraints of groundnut production in selected drylands of Ethiopia. DCG Report No. 74

Debesa, G., Gebre, S.L. , Melese, A., Regassa, A., \& Teka, S. (2020). GIS and remote sensing-based physical land suitability analysis for major cereal crops in Dabo Hana district, South-West Ethiopia, Cogent Food \& Agriculture, 6:1, 1780100 https://doi.org/10.1080/23311932.2020.1780100

FAO, (1997). Participation in Practice: Lessons from the FAO People's Participation Programme. FAO. 
FAO. (1976). A framework for land evaluation. Rome, Italy: Author.

FAO. Food and Agriculture Organization .(1976). A framework for land evaluation. FAO Soil Bulletin No. 32; FAO Rome.;1721

FAOSTAT. (2010). Groundnut world production. http://www.faostat.fao.org.

Gbèhounou, G. and Adengo, E. (2003). From a crop rotation experiment at Akron. Effect of citric acid on aflatoxin degradation and on functional and textural. Food Research International, Volume 42, Issue 8.

Girma, R., Moges, A., Quraishi, S. (2015). GIS Based Physical Land Suitability Evaluation for Crop Production in Eastern Ethiopia: A Case Study in Jello Watershed. Agrotechnol 4: 139. doi:10.4172/21689881.1000139

Girmay, A.B. (2015). Sesame production, challenges and opportunities in Ethiopia

Habibie, Ml., Noguchi, R., Shusuke, M., Ahamed, T. (2019). Land suitability analysis for maize production in Indonesia using satellite remote sensing and GIS-based multi criteria decision support system.

GeoJournal. https://doi.org/10.1007/s10708-019-10091-5

Jahanshiri, E., Nizar, N.M.M., Mohad Suhairi, T.A.S.T., Gregory, P.J., Mohamed, A.S.,Wimalasiri, E.M., AzamAli, S., (2020). A Land Evaluation Framework for Agricultural Diversification. Sustainability.12, 3110.

Kassaye, Hussien., Gezahagn, Woldu; and Shimelis, Birhanu. (2019). A GIS-Based Multi-Criteria Land Suitability Analysis for Surface Irrigation along the Erer Watershed, Eastern Hararghe Zone, Ethiopia. East African Journal of Sciences. Volume 13 (2) 169-184

Kindu, M., Kidanu, S., Chernet. T. (2009). GIS-based Agricultural Land Suitability for Target Crops. EIAR. ISBN 978-99944-53-40-6

Myint, D., Gilani, S.A., Kawase, M., Watanabe, K.N., (2020). Sustainable Sesame (Sesamum indicum L.) Production through Improved Technology: An Overview of Production, Challenges and Opportunities in Myanmar. Sustanability.12, 3515.

Nadeem, A., Kashani, S., Nazeer, A., Buriro, M., Saeed, Z., Mohammad, F., Ahmed, S. (2015). Growth and Yield of Sesame (Sesamum indicum L.) under the Influence of Planting Geometry and Irrigation Regimes. Am. J. Plant Sci. 6:980-986.

Nega, F., Mausch, K., Rao, K.P.C., Legesse, G.(2015). Scoping Study on Current Situation and Future Market Outlook of Groundnut in Ethiopia. Socioeconomics Discussion Paper Series. Series Paper Number 38. ICRISAT, Nairobi, K.Mausch@cgiar.org

Pande, N., Saxena, J. and Pandey, H. (2003) Natural occurrence of mycotoxins in some cereals. Mycoses 33:126-128. 
Rabia, A.H. (2012). A GIS based land suitability assessment for agricultural planning in Kilte Awulaelo district, Ethiopia. The 4th International Congress of ECSSS, EUROSOIL, Bari, Italy

Saaty, T. L. (2002). Decision making with the analytic hierarchy process. Scientia Iranica, 9(3), 215-229. https://doi.org/10.1504/ijssci.2008.017590

Saaty, T.L., (1977). A scaling method for priorities in hierarchical structures. J. Math. Psychol. 15, 234281

Saaty, T.L., (1980). The analytic hierarchy process: planning, priority setting, resources allocation. McGraw, New York, pp. 281.

Sori, O., and Ketema, M. (2017). Determinants of Marketed Surplus of Groundnut Producers in Digga District of Oromia State, Ethiopia. Industrial Engineering Letters www.iiste.org ISSN 2224-6096 (Paper) ISSN 2225-0581

(online) Vol.7, No.8

Sori, O., (2021). Factors Affection groundnut market supply in Western Oromia, Ethiopia. Heliyon, 7, e05892.

Tekulu, K., Taye, G., Assefa, D., (2020). Effect of starter nitrogen and phosphorus fertilizers rates on yield and yield components, grain protein content of groundnut (Arachis Hypogaea L.) and residual soil nitrogen content in a semiarid north Ethiopia. Heliyon, 6, e05101.

Teshome, Y., Kibebew, K., Heluf, G., Sheleme, B. (2013). Physical land suitability evaluation for rain fed production of cotton, maize, upland rice and sorghum in Abobo Area, western Ethiopia. American Journal of Research Communication 1: 296-318.

Upadhyaya, H.D., Reddy, L.J., Gowda, C.L. and Singh, S. (2006) Identification of diverse groundnut germplasm: Sources of early maturity in a core collection. Field Crops Research 97: 261-271

Weiss, E.A., (2000). Sesame, Oilseed Crops. Longman Inc, New York, 131-164.

Zerihun, J. (2012). Sesame (Sesame indicum L.) Crop Production in Ethiopia: Trends, Challenges and Future Prospects. Science, Technology and Arts Research Journal, 1(3): 01-07. ISSN: 2226-7522(Print) and 2305-3327 (Online).

\section{Figures}




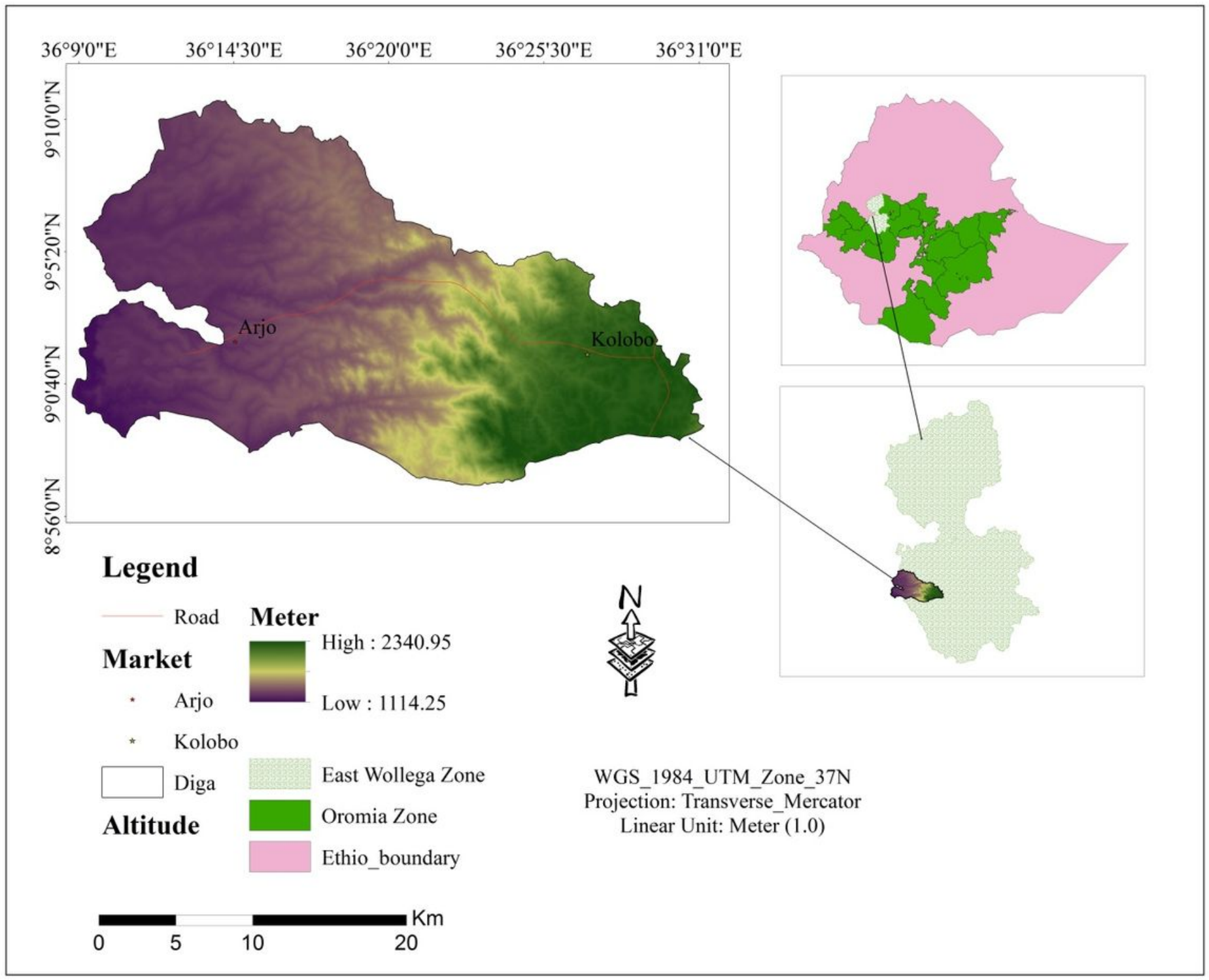

\section{Figure 1}

Location map of the study area 


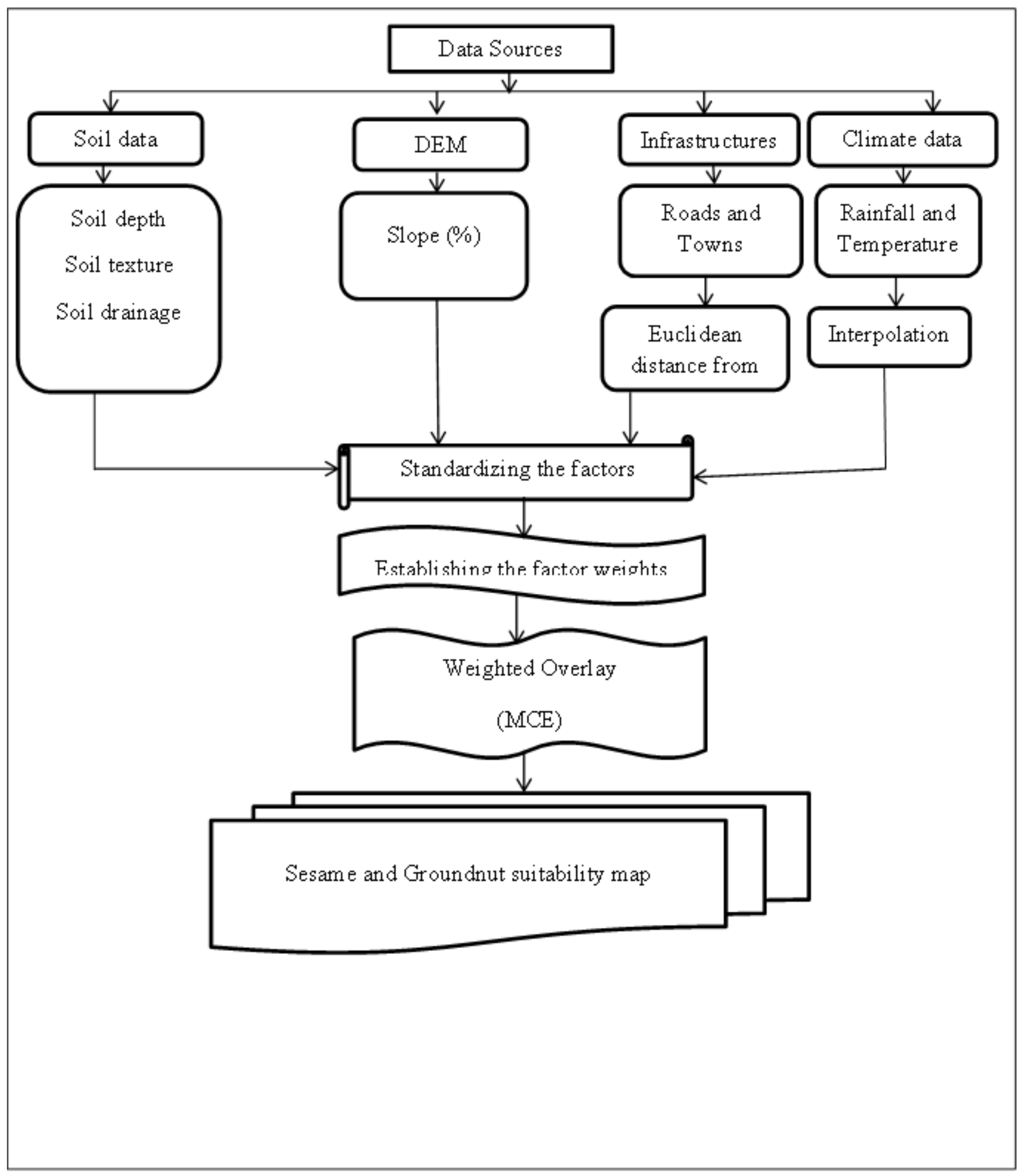

Figure 2

Flow diagram of the study 


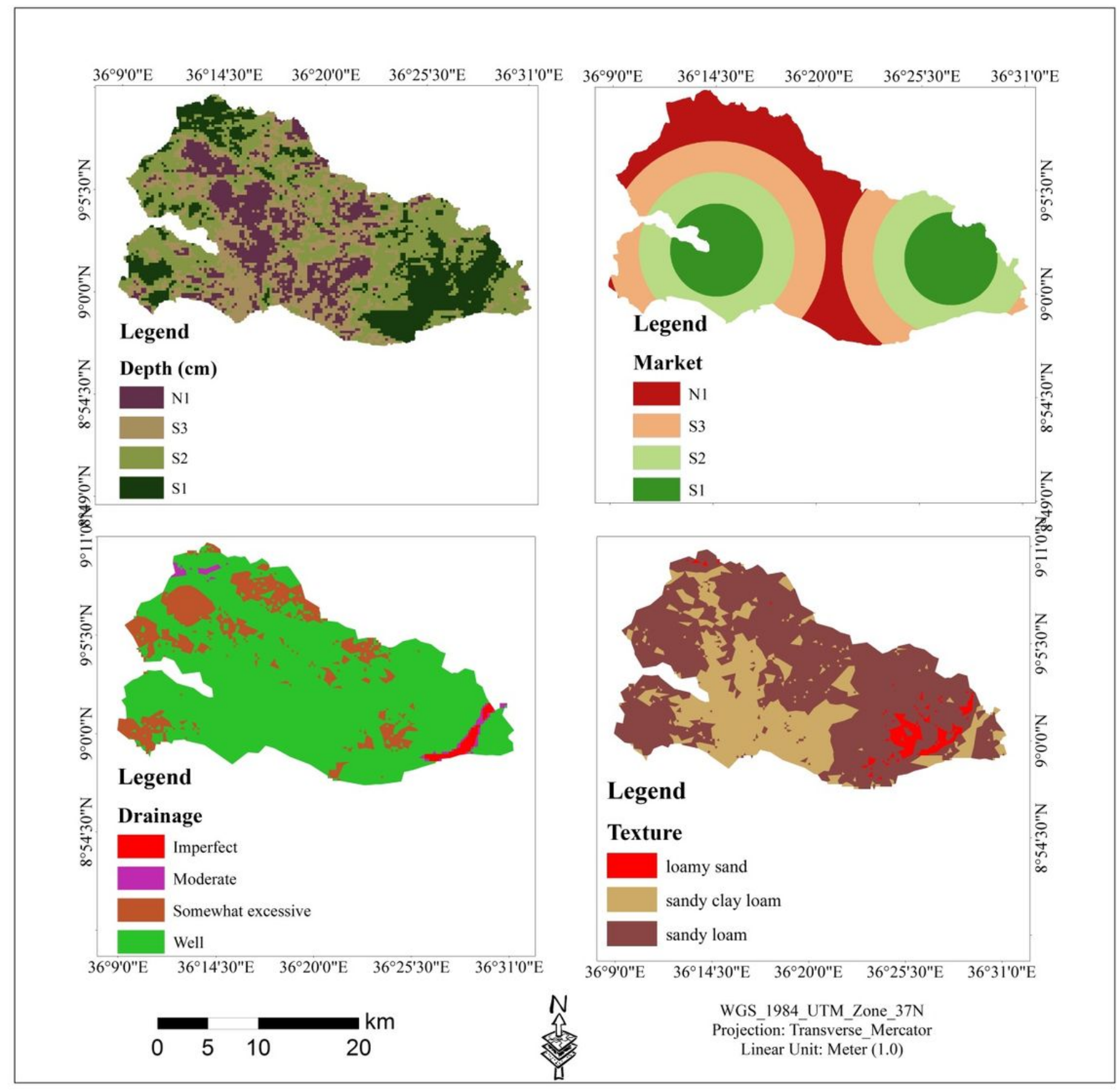

Figure 3

Soil data (depth, drainage and texture) and market 


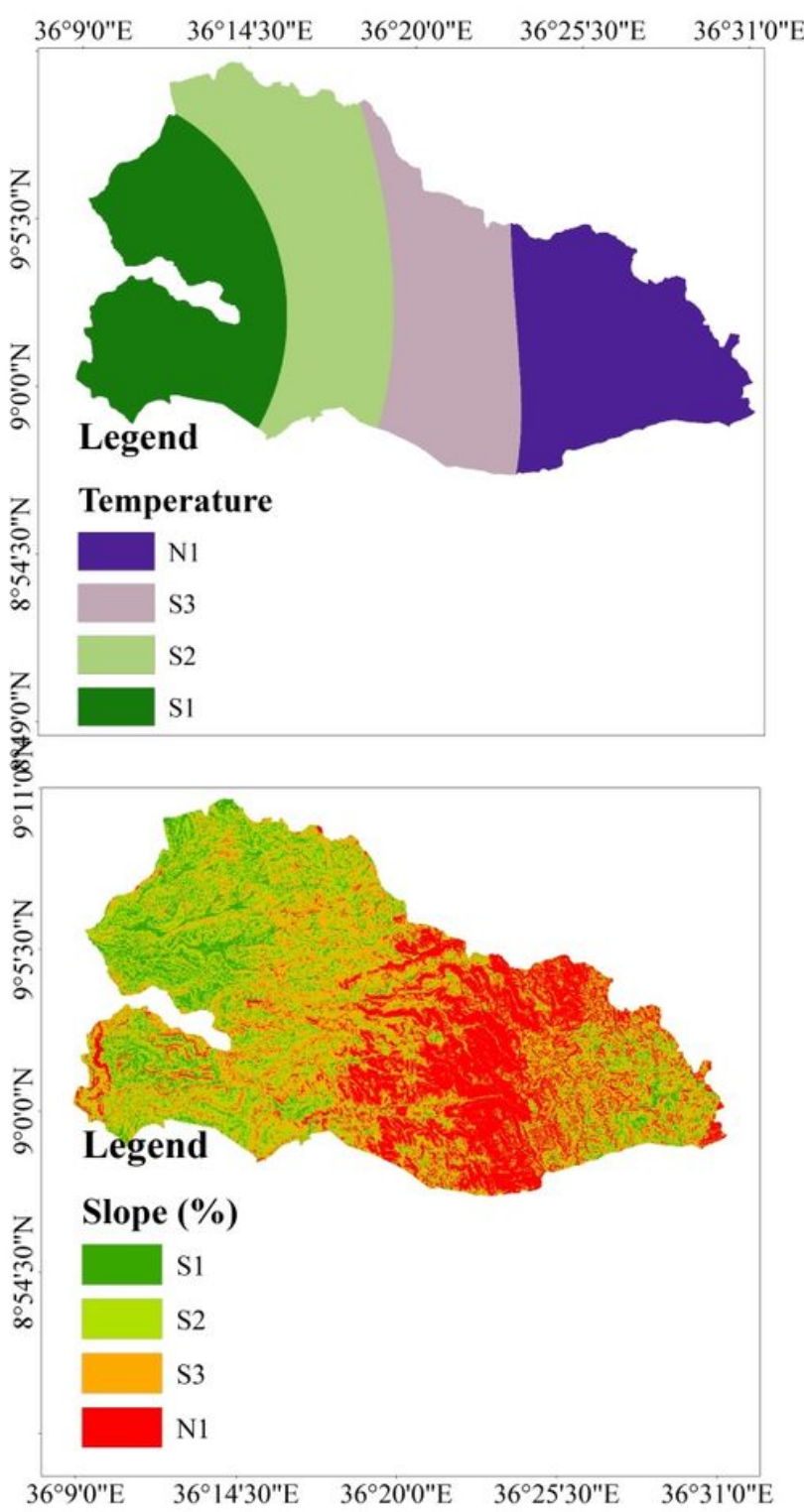

$36^{\circ} 9^{\prime} 0^{\prime \prime} \mathrm{E} \quad 36^{\circ} 14^{\prime} 30^{\prime \prime} \mathrm{E} \quad 36^{\circ} 20^{\prime} 0^{\prime \prime} \mathrm{E} \quad 36^{\circ} 25^{\prime} 30^{\prime \prime} \mathrm{E} \quad 36^{\circ} 31^{\prime} 0^{\prime \prime} \mathrm{E}$

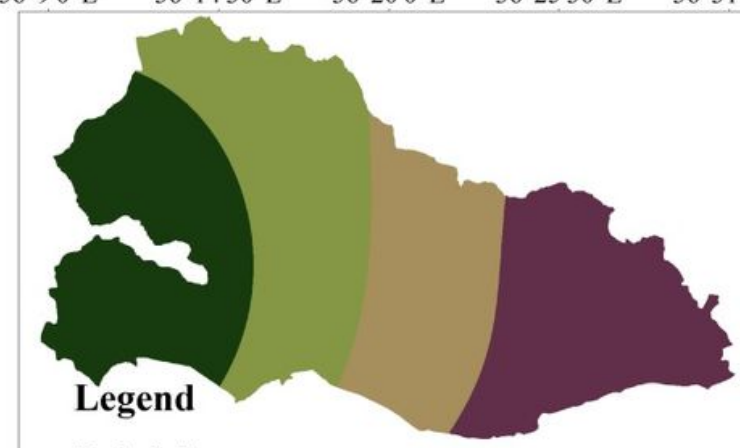

לू.

Rainfall

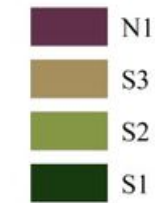

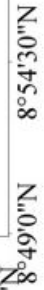
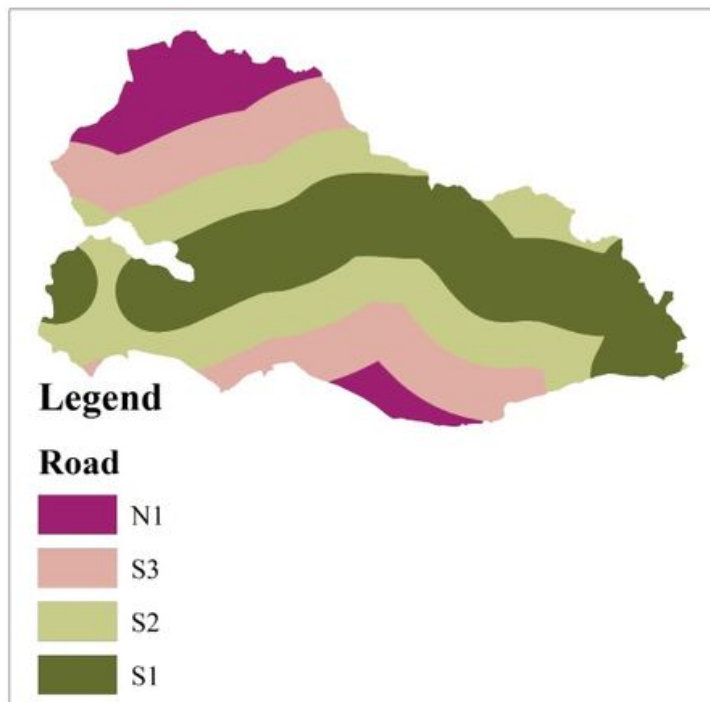

$36^{\circ} 9^{\prime} 0^{\prime \prime} \mathrm{E} \quad 36^{\circ} 14^{\prime} 30^{\prime \prime} \mathrm{E} \quad 36^{\circ} 20^{\prime} 0^{\prime \prime} \mathrm{E} \quad 36^{\circ} 25^{\prime} 30^{\prime \prime} \mathrm{E} \quad 36^{\circ} 31^{\prime} 0^{\prime \prime} \mathrm{E}$

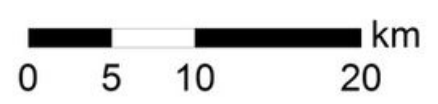

WGS_1984_UTM_Zone_37N

Projection: Transverse_Mercator Linear Unit: Meter (1.0)

Figure 4

Temperature, Rainfall, Slope and Road 


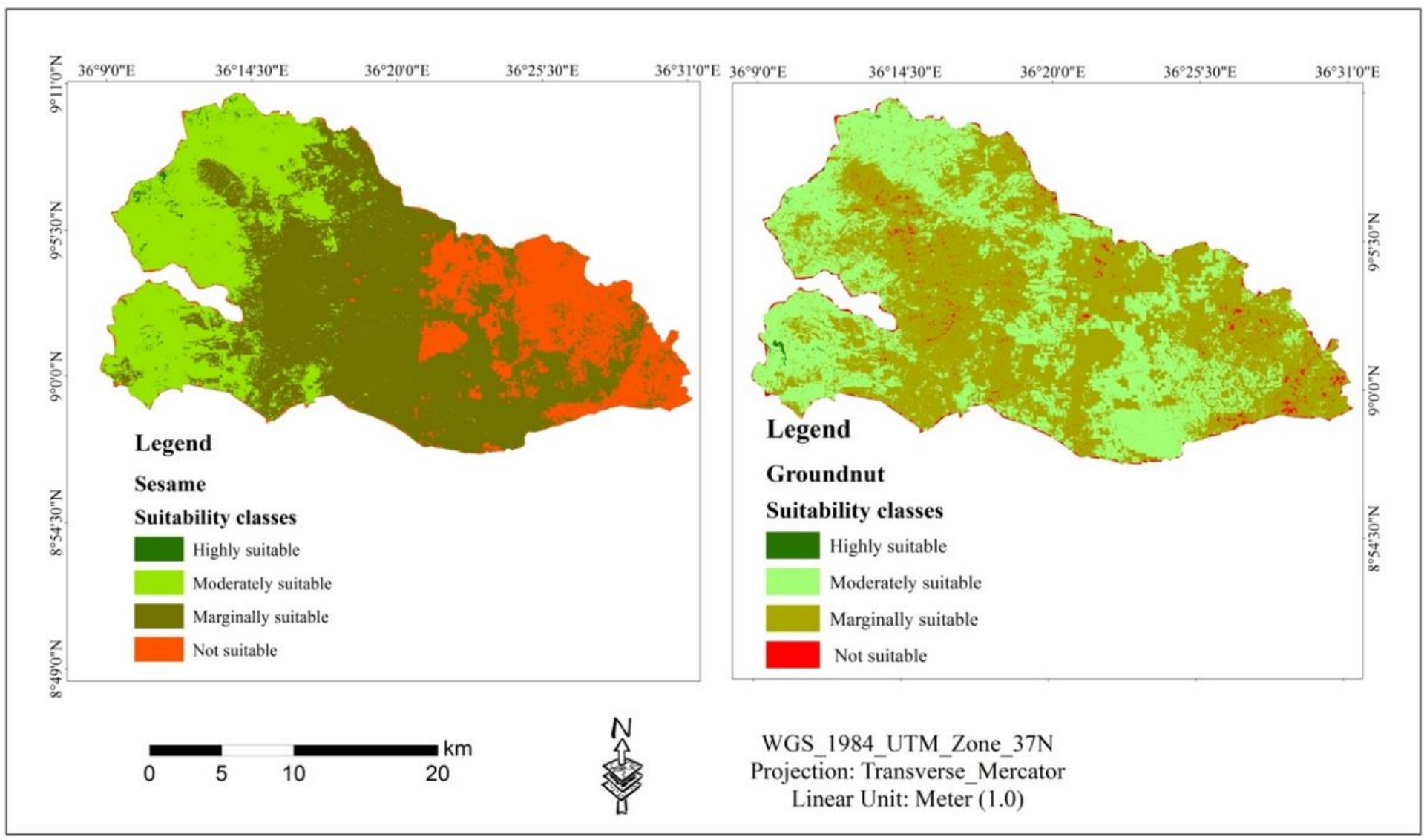

Figure 5

Suitable map of Sesame and Groundnut in the Diga district 